\title{
MISTRAL MISTRAL
}

Journal of Latin American Women's

Intellectual \& Cultural History

\section{Memorias trenzadas/Braided Memories by Marjorie Agosín (review)}

Inela Selimovic, Wellesley College, US

To cite this review: Inela Selimovic. 2021. Review of Memorias trenzadas/Braided Memories by Marjorie Agosín. Mistral: Journal of Latin American Women's Intellectual \& Cultural History 1 (1): 141-143, https://doi.org/10.21827/mistral.1.37513 
Marjorie Agosín, Memorias trenzadas/Braided Memories. Tunbridge Wells: Solis Press, 2020. 240 pp. ISBN: 978-191-0146-38-5

En Braided Memories/Memorias trenzadas (2020) de Marjorie Agosín la fotografía acompaña sus versos. Las fotografías en la colección, cuya fuente es la mano artística del fotógrafo chileno Samuel Shats, se despliegan de manera multidimensional: vemos los paisajes reconocibles; paseamos por los espacios sudamericanos y europeos, nos enfrentamos con los mundos habitados, deshabitados, tangibles y abstractos. Este libro poético-fotográfico - una colección elegantemente armada en español e inglésprimordialmente parece querer rescatar el patrimonio familiar de Helena Broder, la bisabuela de la poeta, para hacernos afrontar mnemónicamente ciertas realidades del Holocausto a nivel colectivo y universal. Los poemas de Agosín en Memorias trenzadas piensan entre imágenes fotográficas simbólica y literalmente y así revelan un viaje singular hacia el dolido pasado colectivo judío del siglo XX.

Las palabras e imágenes de la poeta son portadoras de sentido que se inicia en 1938 en el contexto europeo. El libro plantea el tema del desplazamiento judío temática y visualmente, iniciando el libro con la fotografía del pasaporte de Helena Broder. Destacada al principio del libro, dicha fotografía, con toda su simpleza de indicar los datos básicos de la viajera, encarna directamente el comienzo de la destrucción colectiva judía bajo el régimen nazi. Los detalles de esta fotografía convocan varias preguntas antes de que nos entreguemos a la lectura sobre el trasfondo de la mujer del pasaporte, sus acompañantes, su supervivencia, la vida que había dejado atrás al irse a Sudamérica, entre muchas otras. La fotografía nos obliga pensar en el desplazamiento forzado y su multifacético significado a nivel existencial y emocional: el miedo, la incertidumbre, la ansiedad de replantar ciertas expectativas del mundo sociocultural de la comunidad vienesa a la de Valparaíso, de Austria a Chile, es decir, todo de manera ad hoc. Las complejidades de la reubicación lingüística y existencial, e inevitablemente sociocultural, parece ser la fuerza motriz de esta colección que empuja a los lectores dentro y fuera de sus espacios poéticos y las consecuencias tangibles de los sobrevivientes y los que fueron asesinados indiscriminadamente.

El libro está dividido en cuatro secciones. La primera sección, "Desde los sueños me llamas," celebra poéticamente las invitaciones desde los espacios creativo-oníricosla memoria, la imaginación, los sueños, la música y los artefactos palpables e impalpables - no sólo al plantear un puente mnemónico hacia el pasado de Broder sino también, como ya se ha subrayado, al interactuar con las huellas tangibles de la bisabuelasus fotografías y pertenencias. La sección inicial está anclada en las páginas antepuestas, las que señalan el rostro de la bisabuela, la musa singular de Agosín para estos versos. Aparte de contextualizar históricamente la colección de Agosín sutilmente, dicha fotografía también e innegablemente convoca la conmoción, la atención a y el recuerdo de la destrucción sistemática de comunidades judías. La primera sección empieza con el verso "El prodigio sueño me fue llamando/me fue pidiendo que te encontrara" ("El prodigio del sueño", 41) y termina con los versos que parecen unir a la poeta con su bisabuela metafóricamente, cuya reunión se manifiesta vivificada a través del acto creativo, la palabra escrita, en "Tengo yo hoy tu edad, una vida plena ...Quiero que me oigan/que los quiero encontrar/encontrar en mi memoria/otorgar esta memoria a otros ("Un entierro 
azul", 67). Como si fuera un preludio a la historia detrás de la fotografía de Helena, esta sección traza los procesos de querer recordar tal vez a base de pocas memorias personales de la poeta y un sinnúmero de historias familiares sobre su supervivencia y su llegada a Chile. El desplazamiento, plasmado en la fotografía de la bisabuela al principio de la colección, comienza a concretizarse a través de los poemas que, a veces, detallan y, otras veces, averiguan las especificidades de la travesía de la exiliada.

La segunda sección, "Viena la caprichosa," es una reunión anhelosa con las huellas existenciales de la bisabuela en los espacios europeos que genera curiosidades, preguntas, memorias e historias. Los versos plasman una multifacética intersección, cargada de sinestesia, donde lo histórico se encuentra frecuentemente con lo imaginado: el olor de "la llovizna" y "las lilas" el aire de "las ciudades quemadas" europeas, los "campos de cenizas", "las mujeres calvas flotan", "las nieblas más sombrías" y "Viena libre de judíos" $(75,79,101,103,111,115,121)$. Los espacios que paulatinamente visitamos son simultáneamente reconocibles y culturalmente relevantes, ya que entramos en Auschwitz, en los cementerios judíos y en las sinagogas austriacas. A parte de las fotografías que auténticamente acompañan ciertos espacios de los poemas, esta sección también articula un recorrido de preguntas existenciales y elementales como se nota en los poemas "Las pertenencias abandonadas", "Tu maleta" y "La casa vacía." Esta sección busca unir varias partes de la vida interrumpida y la apenas salvada a nivel sumamente sobrecogedor, evocando las consecuencias de la perturbadora destrucción nazista.

La segunda parte de la colección se despliega en dos secciones, es decir, "Chile, una estrella al fin del mundo" y "La casa de la memoria." En "Tan solo el mar," el Holocausto se deja atrás, pero sus consecuencias persisten. La llegada de la abuela se retrata de manera resplandeciente, pero también nos hace pensar en lo que había dejado atrás-la pérdida de sus seres queridos:

Tú asomándote al nuevo mundo

con tus guantes de seda,

con tu mirada de ámbar,

con tu caminar dulce,

con tu sonrisa de media luna.

Así me contó mi madre

cuando te vio haciéndote señas.

El día que llegaste, Helena Broder, al puerto de Valparaíso,

el día que te asomaste a la vida nueva. (143)

Éstos-y el resto de los versos de esta sección-rebosan de la materialidad del desplazamiento a través de las inseguras memorias y firmes curiosidades del yo lírico. Dicha materialidad se inicia con preguntas que oscilan entre el mundo abandonado (Viena) y el recién inhabitado (Chile), es decir, “A quién buscabas?”, ¿Cómo era tu memoria?”, “¿Cubriste los espejos en señal de la presencia austera de la muerte?” (145, 147, 149). Esta sección, a ultranza, reconstruye la intimidad de la intersubjetividad que compartían la bisabuela y la bisnieta-poeta a través de las interacciones llenas de fascinación, afectos e imprecisión. En el medio de estas interacciones, se halla la naturaleza chilena como si fuera la interlocutora sutil con los recién llegados, desplazados y exiliados. La flora y fauna 
chilena parece mediatizar las interacciones de la sobreviviente, Helena, con su entorno, su familia, su nuevo mundo. "Luciérnagas regresan," por ejemplo, encarna dicho aspecto magníficamente mientras leemos:

\author{
Ambas las luciérnagas \\ que llegaban a tu cabello \\ para que yo las encontrara. \\ Así jugábamos \\ sin decirnos nada. \\ Entre tú y yo, \\ la intuición del amor. (197)
}

El paso del tiempo se marca sutilmente en la siguiente sección a través de las referencias directas a la vejez de la bisabuela. Ciertos versos hacen que la vejez sea palpable para que la imaginemos en concreto, pues "Ahora los días y las noches transcurren sin calendarios/ Perdida en los tiempos/ has pactado con los olvidos" ("La bendición del olvido" 201). A través de la última sección, la lectora regresa al espacio chileno contemporáneo de manera algo etnográfica, deambulando por las calles, rincones, costas, la casa que ocupaba Helena, y, más que nada, entre sus propias memorias y cuentos heredados. Estos poemas culminan en la celebración de la vida y del espacio familiar que guardaban tal vez los detalles sobre Helena de haberse sentido paradójicamente borrada, renacida, aceptada, celebrada, conmemorada y honrada.

Memorias trenzadas parece ser un álbum familiar singular; un álbum judío a la vez onírico y verdadero, configurado de los viajes lejanos y contemporáneos para resaltar la singularidad de silencios, memorias, curiosidades y preguntas sobre un contexto política y existencialmente devastador. Los poemas de Memorias trenzadas surgen como ejes sustentadores de los mundos fotográficos y las fotografías de Shats como sus marcos ostensibles, resplandeciendo su espíritu fusionado y solemnizador para la posteridad.

Inela Selimovic

Wellesley College 